\title{
ALEKSANDRA WOJCIECHOWSKA
}

\section{Bezskuteczność a nieważność niedozwolonych postanowień umownych w umowach ubezpieczenia}

Celem niniejszego artykułu jest ustalenie która z sankcji - bezskuteczność czy nieważność - umowy zawartej przy użyciu ogólnych warunków ubezpieczenia, w przypadku wystapienia w jej treści niedozwolonych postanowień umownych pozostajacych zarazem w sprzeczności z prawem lub zasadami współżycia społecznego, lepiej zabezpiecza interesy ubezpieczajacego, będqcego jednocześnie konsumentem. Ze względu na masowy charakter umowy ubezpieczenia sq w praktyce zawierane przy użyciu wzorców umownych, które nie stanowiq przedmiotu negocjacji między stronami, a ich treść jest samodzielnie kształtowana przez ubezpieczyciela. W zwiqzku z tym powstała potrzeba zapewnienia ubezpieczajqcemu odpowiedniego poziomu ochrony, którego celem była eliminacja nadużywania przez ubezpieczycieli ich silniejszej pozycji na rynku, przejawiajacej się możliwościa kształtowania uprawnień i obowiqzzów stron na niekorzyść ubezpieczajqcego. Jednym z przejawów takich działań było ukształtowanie regulacji dotyczacych umowy ubezpieczenia w przeważajacej części w formie przepisów ius cogens. W takim przypadku to właśnie na gruncie umów ubezpieczenia istnieje duże prawdopodobieństwo, że sformułowane przez ubezpieczyciela postanowienia wzorca umownego moga spełniać przesłanki z art. $385^{1}$ k.c. wskazujqce na niedozwolony charakter klauzul, a jednocześnie pozostawać w sprzeczności z prawem lub zasadami współżycia społecznego.

Słowa kluczowe: niedozwolone postanowienia umowne, klauzule abuzywne, wzorzec umowny, ogólne warunki ubezpieczenia, bezskuteczność, nieważność, umowa ubezpieczenia.

\section{Wstęp}

Zagadnienie niedozwolonych postanowień umowy ubezpieczenia ma duże znaczenie praktyczne. Nie ulega wạtpliwości, że umowa ubezpieczenia zalicza się do kontraktów, które w przeważającej mierze maja charakter adhezyjny. Masowy charakter umów ubezpieczenia i potrzeba zapewnienia ubezpieczającemu, będącemu zarazem konsumentem - jako słabszej stronie kontraktu 
- odpowiedniej ochrony przyczyniły się do ukształtowania przez ustawodawcę regulacji dotyczących umowy ubezpieczenia w znacznej większości w formie przepisów o charakterze bezwzględnie wiążącym. ${ }^{1} \mathrm{~W}$ związku z powyższym w odniesieniu do umowy ubezpieczenia istnieje duże ryzyko, że zaproponowane przez ubezpieczyciela postanowienia wzorca umownego, kształtujące prawa i obowiązki ubezpieczonego moga spełniać przesłanki z art. $385^{1}$ k.c. wskazujące na niedozwolony charakter zawartych we wzorcu klauzul, a jednocześnie pozostawać w sprzeczności z prawem lub zasadami współżycia społecznego. W takiej sytuacji powstaje wątpliwość, która sankcje zastosować do takich postanowień, czy pierwszeństwo ma sankcja nieważności z art. 58 k.c., czy bezskuteczności z art. $385^{1}$ k.c. jako lex specialis względem przepisu dotyczącego nieważności bezwzględnej. Niniejszy artykuł ma na celu ustalenie, która z sankcji - bezskuteczność czy nieważność -lepiej zabezpiecza interesy ubezpieczającego, a zarazem znajduje uzasadnienie w świetle aktualnie obowiązujących przepisów prawa i poglądów doktryny.

\section{Niedozwolone postanowienia umowne}

\subsection{Wprowadzenie}

Postanowienia umowne, w których dochodzi do nadużycia pozycji kontraktowej przez przedsiębiorcę na niekorzyść konsumenta, zwane również klauzulami abuzywnymi² stanowią przedmiot regulacji dyrektywy Rady 93/13/EWG z dnia 5 kwietnia 1993 roku w sprawie nieuczciwych warunków w umowach konsumenckich ${ }^{3}$ (dalej: dyrektywa 93/13). W myśl art. 3.1 dyrektywy 93/13 klauzule umowne, które nie były indywidualnie negocjowane przez strony kontraktu, moga być uznane za nieuczciwe, jeśli stoją w sprzeczności z wymogami dobrej wiary oraz powodują znaczącą dysproporcję wynikajacych z kontraktu uprawnień i obowiązków stron - na niekorzyść konsumenta.

W polskim porządku prawym jednym z wyrazów implementacji postanowień dyrektywy 93/13 jest art. $385^{1}$ k.c. Przepis ten reguluje instytucję niedozwolonych postanowień umownych, przez które należy rozumieć postanowienia zawarte w umowie z udziałem konsumenta, które nie zostały z nim uzgodnione indywidualnie oraz kształtujajego prawa i obowiązki w sposób sprzeczny z dobrymi obyczajami, jednocześnie rażąco naruszając jego interesy. Jednakże za abuzywne nie moga zostać uznane postanowienia dotyczące głównych świadczeń stron umowy, pod warunkiem, że zostały sformułowane w sposób jednoznaczny i zrozumiały dla adresata tych klauzul. Innymi słowy: uznanie danego postanowienia umownego za niedozwolone jest możliwe tylko w przypadku kumulatywnego spełnienia ustawowych przesłanek przewidzianych w art. $385^{1}$ k.c.

1. M. Krajewski, Umowa ubezpieczenia a niedozwolone postanowienia umowne, „Wiadomości Ubezpieczeniowe” 2013, nr 1 (specjalny), s. 31.

2. M. Bednarek, Wzorce umów, [w:] System prawa prywatnego. Tom 5. Prawo zobowiqzań - część ogólna, [red.] E. Łętowska, CH Beck, Warszawa 2013, s. 735.

3. Dyrektywa Rady 93/13/EWG z dnia 5 kwietnia 1993 r. w sprawie nieuczciwych warunków w umowach konsumenckich (Dz. Urz. UE.L Nr 95). 


\subsection{Przesłanki uznania postanowień umownych za niedozwolone we wzorcach umów ubezpieczenia}

Pierwszą przesłankạjest możliwość uznania danego postanowienia za niedozwolone tylko w przypadku umów zawartych z udziałem konsumenta. Z orzecznictwa Trybunału Sprawiedliwości wynika, że system ochrony ukształtowany przez dyrektywę 93/13 opiera się na założeniu, że konsument jest podmiotem słabszym w relacji z przedsiębiorca, zarówno pod względem negocjacyjnym, jak i z uwagi na skalę poinformowania ${ }^{4}$. Zgodnie z treścią art. $22^{1}$ k.c. konsumentem jest osoba fizyczna dokonująca z przedsiębiorcą czynności prawnej, która nie wykazuje bezpośredniego związku z jej działalnościa gospodarczą lub zawodową. Jednakże w przypadku umowy ubezpieczenia art. 805 par. 4 k.c. Stanowi, że przepisy art. $385^{1}-385^{3}$ k.c. dotyczące niedozwolonych postanowieniach umownych stosuje się odpowiednio, jeżeli ubezpieczającym jest osoba fizyczna, która zawiera umowę ubezpieczenia związaną bezpośrednio z jej działalnością gospodarczą lub zawodowa. Oznacza to, że na mocy tego przepisu ustawodawca rozszerzył ochronę wynikająca z klauzul abuzywnych również na osoby fizyczne występujące w charakterze przedsiębiorców. ${ }^{5}$ Jednakże unormowanie to nie prowadzi do sytuacji, w której drobni przedsiębiorcy stają się konsumentami w rozumieniu art. $22^{1}$ k.c., a jedynie poprzez odpowiednie stosowanie przepisów regulujących instytucję klauzul abuzywnych podmioty te korzystają z określonego zakresu ochrony, jaka przysługuje konsumentom na mocy tych przypisów. Obejmując rozszerzoną ochroną tylko drobnych przedsiębiorców będących osobami fizycznymi, ustawodawca kierował się skalą działalności gospodarczej prowadzoną przez te podmioty. Uznał bowiem, że z reguły prowadzona przez drobnych przedsiębiorców działalność cechuje się mniejszą skalą niż działalność prowadzona przez osoby prawne czy jednostki organizacyjne nieposiadające osobowości prawnej, co w konsekwencji stanowi podstawę dysproporcji pozycji ekonomicznej i kontraktowej tych podmiotów względem ubezpieczyciela. ${ }^{6}$

Druga przesłanką uznania postanowień umownych za niedozwolone jest nieuzgodnienie indywidualnie z konsumentem danej klauzuli umownej. Przyjmuje się, że klauzule umowne nie są indywidualnie uzgodnione, gdy zostały sporządzone przez profesjonalistę przed zawarciem umowy, bez konsultacji z konsumentem, a w związku z tym ten ostatni był pozbawiony rzeczywistego wpływu na ich treść?. Dyrektywa 93/13 wskazuje jako przykład klauzul niewynegocjowanych indywidualnie w szczególności postanowienia umowy standardowej, której celem jest kształtowanie nieograniczonej liczby kontraktów. W polskim porządku prawnym za synonim pojęcia umowy standardowej uznawany jest termin wzorca umownego. ${ }^{8} \mathrm{~W}$ praktyce na rynku ubezpieczeniowym zawierane są umowy ubezpieczenia, które należą do umów masowych. W celu

4. Wyrok Trybunału Sprawiedliwości Unii Europejskiej (dalej: TSUE) z dnia 29 października 2015 r., C-8/14, Legalis nr 1349286 [dostęp: 17.05.2018].

5. M. Krajewski, op. cit., s. 35.

6. M. Krajewski, Art. 805, [w:] Umowa ubezpieczenia. Art. 805-834 k.c. Komentarz, CH Beck, Warszawa 2016, nb. 50, Legalis [dostęp: 17.05.2018].

7. Por. Wyrok TSUE z dnia 3 czerwca 2010 r., C-484/08, Legalis nr 222721 [dostęp: 17.05.2018].

8. M. Rejdak, Definicja terminu „wzorzec umowy konsumenckiej”, „Ruch Prawniczy, Ekonomiczny i Socjologiczny" 2005, z. 3, s. 122. 
ułatwienia ich zawarcia ubezpieczyciele posługują się gotowymi wzorcami umownymi, które nie stanowią przedmiotu negocjacji między stronami, a ich treść jest narzucona ubezpieczającemu przez ubezpieczyciela. ${ }^{9}$ Ponadto dyrektywa 93/13 wprowadza zasadę, zgodnie z która sam fakt, iż niektóre klauzule lub poszczególne jej części były przedmiotem indywidualnych negocjacji stron, nie wyklucza możliwości poddania pozostałej części umowy kontroli pod kątem jej abuzywności, jeżeli z ogólnej oceny umowy wynika, że mamy do czynienia ze wzorcem umownym, przygotowanym uprzednio przez przedsiębiorcę. Ciężar udowodnienia, że postanowienie zostało indywidualnie uzgodnione, spoczywa na tym podmiocie, który powołuje się na tę okoliczność.

Dwie kolejne przesłanki, tj. sprzeczność z dobrymi obyczajami i rażące naruszenie interesów konsumenta, muszą być spełnione łącznie. Wynika to zarówno z brzmienia samego art. $385^{1}$ par. 1 k.c., jak i z dorobku orzeczniczego polskich sądów. Zgodnie z wyrokiem Sądu Najwyższego do uznania danego postanowienia wzorca umownego za niedozwolone niezbędne jest stwierdzenie, że prowadzi ono do rażącej dysproporcji uprawnień i obowiązków stron kontraktu ${ }^{10}$. Przy czym wskazać należy, że samo ukształtowanie praw i obowiązków konsumenta w sposób sprzeczny z dobrymi obyczajami nie przesądza jednocześnie o naruszeniu jego interesów i to w dodatku w znaczącym zakresie, dlatego też za celowe należy uznać wprowadzenie przez ustawodawcę przesłanki w postaci rażącego naruszenia interesów konsumenta. Pojęcie dobrych obyczajów stanowiące klauzulę generalną nie zawiera normatywnej definicji, w związku z tym dużą rolę odgrywa tutaj doktryna. Przez działanie kontrahenta w sposób sprzeczny z dobrymi obyczajami można rozumieć szeroko pojmowany brak szacunku względem konsumenta oraz naruszenie równowagi interesów stron umowy, poprzez nadużycie pozycji rynkowej przez stronę silniejszą. ${ }^{11}$ Znajduje to swoje uzasadnienie w orzecznictwie Sądu Najwyższego, zgodnie z którym pojęcie ukształtowania uprawnień i obowiązków konsumenta w sposób sprzeczny z dobrymi obyczajami, w zakresie formułowania treści postanowień umownych, przejawia się w tworzeniu przez przedsiębiorcę takich klauzul, które godzą w równowagę kontraktową stron - na niekorzyść konsumenta ${ }^{12}$. Ponadto do dobrych obyczajów należy zaliczyć wymaganie od profesjonalisty stosowania w wzorcach umownych takich klauzul, które dla przeciętnego adresata będą jasne i czytelne oraz nie będą budziły wạtpliwości, a także umożliwią poszanowanie jego interesów i uprawnień wynikających z przepisów prawa ${ }^{13}$. Uznaje się również, że przedsiębiorca respektuje dobre obyczaje, a w odniesieniu do dyrektywy 93/13 - zasadę dobrej wiary, w przypadku gdy traktuje on druga stronę umowy w sposób sprawiedliwy i słuszny ${ }^{14}$. Ponadto przy dokonywaniu oceny działania przedsiębiorcy pod kątem zgodności tych działań z zasadami dobrej wiary należy brać pod uwagę zwłaszcza siłę kontraktową stron, a w szczególności kwestię, czy przedsiębiorca, nadużywając silniejszej pozycji rynkowej,

9. S. Wieteska, Nieuczciwe praktyki na rynku ubezpieczeniowym - klauzule abuzywne, „Annales. Etyka w życiu gospodarczym" 2011, nr 2, s. 129.

10. Wyrok Sądu Najwyższego (dalej: SN) z dnia 29 sierpnia 2013 r., I CSK 660/12, Legalis nr 83057 ? [dostęp: 17.05.2018]. Por. Wyrok Sądu Apelacyjnego (dalej: SA) w Warszawie z dnia 26 kwietnia 2013 r., VI ACa 1571/12, Legalis nr 739528 [dostęp: 17.05.2018].

11. R. Sikorski, P. Ruchała, Art. 3851, [w:] Kodeks cywilny. Tom I. Komentarz. Art. 1-44911, [red.] M. Gutowski, CH Beck, Warszawa 2016, nb. 12, Legalis [dostęp: 17.05.2018].

12. Wyrok SN z dnia 27 października 2006 r., I CSK 173/06, Legalis nr 304562 [dostęp: 17.05.2018].

13. Wyrok SA w Warszawie z dnia 13 marca 2014 r., VI ACa 1733/13, Legalis nr 993871 [dostęp: 17.05.2018].

14. Akapit 14 preambuły dyrektywy $93 / 13$. 
nie wywierał presji na konsumencie w celu wyrażenia zgody na proponowaną klauzulę umowna.. ${ }^{15}$ Oceny, czy doszło do kształtowania uprawnień i obowiązków stron kontraktu w sposób sprzeczny z dobrymi obyczajami, dokonuje się według stanu z chwili zawarcia umowy, uwzględniając treść kontraktu, okoliczności, w jakich doszło do jego zawarcia, oraz biorąc pod uwagę pozostajace w związku z umową inne porozumienia. ${ }^{16}$

Natomiast zgodnie z orzeczeniem Sądu Apelacyjnego w Szczecinie ocena, czy dane postanowienie umowne, kształtujące uprawnienia i obowiązki konsumenta, „rażąco” narusza jego interesy, uzależniona jest od tego, czy wynikająca z tego postanowienia dysproporcja kontraktowa jest znacząca ${ }^{17}$. Jak wskazuje Małgorzata Bednarek, z istotnym naruszeniem interesu konsumenta mamy do czynienia wtedy, gdy dochodzi do rażącego odchylenia przyjętego uregulowania od uczciwego i sprawiedliwego wyrażania uprawnień i obowiązków stron. ${ }^{18}$ Jako przykład klauzuli sprzecznej z dobrymi obyczajami i rażąco naruszającej interes konsumentów w działalności ubezpieczeniowej (wpisanej zresztą do rejestru klauzul niedozwolonych prowadzonego przez Prezesa Urzędu Ochrony Konkurencji i Konsumentów) może posłużyć klauzula nr 1311, zgodnie z która „Umowę ubezpieczenia uważa się za zawartą z chwilą doręczenia ubezpieczającemu polisy lub innego dokumentu ubezpieczenia" ${ }^{19}$. Zdaniem sądu art. 802 par. 2 k.c. traktuje chwilę doręczenia polisy jako moment zawarcia umowy ubezpieczenia wyłącznie w razie wątpliwości co do chwili jej zawarcia, a nie, jak to stanowi klauzula nr 1311, w każdym przypadku. Innym przykładem jest klauzula nr 1237, 1238, 1239, 1240 i 1241 zgodnie z która „W razie wypowiedzenia lub odstapienia od umowy składka za niewykorzystany okres ubezpieczenia podlega zwrotowi tylko wtedy, gdy w okresie ubezpieczenia nie wystapiła szkoda, za którą ubezpieczyciel wypłacił lub zobowiązany jest do wypłacenia odszkodowania lub świadczenia." ${ }^{20} \mathrm{~W}$ tym przypadku sąd uznał, że ubezpieczycielowi nie należy się składka za okres, w którym ochrona ubezpieczeniowa nie była świadczona, a konsumentowi należy się zwrot składki w zakresie niewykorzystanego okresu ubezpieczenia.

\subsection{Główne świadczenie stron w umowie ubezpieczenia a klauzule abuzywne}

Postanowienia wzorca umownego, mimo że odpowiadają wyżej wymienionym przesłankom, nie stanowia klauzul abuzywnych, jeżeli dotycza głównych świadczeń stron i jednocześnie zostały sformułowane w sposób jednoznaczny. W jednym z orzeczeń Trybunał Sprawiedliwości utożsamia pojęcie „główne świadczenia stron” z głównym przedmiotem umowy, wskazując, że nie obejmuje ono swoim zakresem postanowień, które wykazujajedynie charakter posiłkowy względem klauzul,

15. M. Bednarek, op. cit., s. 739 .

16. Wyrok Sądu Okręgowego (dalej: SO)w Warszawie z dnia 5 września 2017 r., XXV C 2053/17, LEX nr 2553051 [dostęp: 17.05.2018].

17. Wyrok SA w Szczecinie z dnia 2 sierpnia 2017 r., I ACa 263/17, Legalis nr 1683524 [dostęp: 17.05.2018].

18. M. Bednarek, op. cit., s. 768 .

19. Wyrok Sądu Okręgowego w Warszawie - Sąd Ochrony Konkurencji i Konsumentów z dnia 11 października 2007 r., XVII AmC 68/06. Orzeczenie zaczerpnięte z Raportu Rzecznika Ubezpieczeniowego Klauzule abuzywne w działalności ubezpieczeniowej, luty 2012, s. 35-36.

20. Wyrok Sądu Okręgowego w Warszawie - Sąd Ochrony Konkurencji i Konsumentów z dnia 25 czerwca 2007 r., XVII AmC 74/07. Orzeczenie zaczerpnięte z Raportu Rzecznika Ubezpieczeniowego Klauzule abuzywne w dziatalności ubezpieczeniowej, luty 2012, s. 16-19. 
które definiuja istotę danego stosunku${ }^{21}$. W umowie ubezpieczenia głównym świadczeniem ubezpieczającego zgodnie z art. 805 par. 1 k.c. jest zapłata składki. Wạtpliwości budzi jednak główne świadczenie ubezpieczyciela. W doktrynie zagadnienie to stanowi przedmiot sporu pomiędzy zwolennikami teorii świadczenia pieniężnego ${ }^{22}$ i teorii ryzyka ${ }^{23}$. Dla zwolenników torii świadczenia pieniężnego głównym świadczeniem ubezpieczyciela w razie zajścia wypadku ubezpieczeniowego jest zapłata przewidzianego w umowie odszkodowania w odniesieniu do ubezpieczeń majątkowych lub umówionej sumy pieniężnej, renty albo innego świadczenia w przypadku ubezpieczeń osobowych. Natomiast zwolennicy teorii ryzyka za główne świadczenie ubezpieczyciela uznają oprócz wskazanych świadczeń również udzielanie ochrony ubezpieczeniowej w czasie trwania umowy. ${ }^{24}$ W powyższym sporze jednoznacznie zajmuję stanowisko na rzecz drugiej z wymienionych teorii, przyjmując, że znajduje ona swoje uzasadnienie w przepisach prawa m.in. w art. 813 par. 1 k.c. zd. 2, w którym ustawodawca wprost określa, że za niewykorzystany okres ochrony ubezpieczeniowej ubezpieczonemu przysługuje zwrot składki oraz w art. 15 ust. 1 ustawy z dnia 11 września 2015 roku o działalności ubezpieczeniowej i reasekuracyjnej ${ }^{25}$ dotyczącym udzielenia ubezpieczającemu przez ubezpieczyciela ochrony ubezpieczeniowej na mocy umowy ubezpieczenia.

Niezależnie od przyjętej koncepcji istotne jest, aby klauzula umowna dotycząca głównego świadczenia była sformułowana przez ubezpieczyciela w sposób jednoznaczny. Innymi słowy dla wyłączenia postanowienia umownego spod kontroli jego abuzywności, a tym samym możliwości uznania go za niewiążące względem konsumenta, konieczne jest dochowanie przez przedsiębiorcę zasady transparentności wzorca z art. 385 par. 2 k.c. Na gruncie umowy ubezpieczenia zasada ta została określona w art. 15 ust. 3 u.dz.u.r., który obliguje ubezpieczyciela do formułowania postanowień umowy ubezpieczenia, ogólnych warunków ubezpieczenia i innych wzorców w sposób zrozumiały i jednoznaczny. Jednakże w odróżnieniu od kodeksowej zasady transparentności wzorca, ta określona w u.dz.u.r. dotyczy nie tylko konsumentów, lecz także przedsiębiorców, z którymi zawierane sa umowy ubezpieczenia ${ }^{26}$. Terminy „jednoznaczność” i „zrozumiałość” oznaczają, że zawarte we wzorcu postanowienia powinny być sformułowane jasno i czytelnie oraz w sposób niebudzący wạtpliwości dla przeciętnego adresata wzorca. ${ }^{27}$ Zgodnie ze stanowiskiem Sądu Najwyższego, proponent ma obowiązek umożliwić konsumentowi zapoznanie się w sposób kompletny i jednoznaczny z informacjami w sprawach, które mają istotne znaczenie dla zabezpie-

21. Wyrok TSUE z dnia 26 lutego 2015 r., C-143/13, Legalis nr 1187366 [dostęp: 18.05.2018].

22. Teorię świadczenia pieniężnego reprezentowali m.in.: V. Ehrenberg, Versicherungsrecht, Duncker \& Humblot, Leipzig 1893, t. I, s. 56 i n..

23. Zwolennikami teorii ryzyka w nauce polskiej są m.in.: B. Kęszycka, Prawo ubezpieczeń gospodarczych, Wyższa Szkoła Bankowa, Poznań 1999, s. 83; D. Fuchs, Wybrane cechy umowy ubezpieczenia majatkowego, „Prawo Asekuracyjne" 1999, nr 4, s. 42; K. Malinowska, Wzajemne umowy ubezpieczenia w świetle orzecznictwa, ustawodawstwa i doktryny, „Prawo Asekuracyjne” 2009, nr 3, s. 22.; Z. Radwański, J. Panowicz-Lipska, Zobowiqzania - część szczegółowa, CH Beck, Warszawa 2001, s. 51.

24. M. Krajewski, Umowa ..., s. 38.

25. Ustawa z dnia 11 września 2015 r. o działalności ubezpieczeniowej i reasekuracyjnej (Dz. U. 2015, poz. 1844, t. jedn. Dz. U. 2018, poz. 999], dalej: u.dz.u.r.

26. E. Bukowska, Art. 15, [w:] Ustawa o działalności ubezpieczeniowej i reasekuracyjnej. Komentarz, [red.] P. Czublun, CH Beck, Warszawa 2016, Legalis [dostęp: 18.05.2018].

27. W. Popiołek, Art.358 ${ }^{1}$, [w: Kodeks cywilny. Tom I. Komentarz od art. 1-449 ${ }^{10}$, [red.] K. Pietrzykowski, CH Beck, Warszawa 2018, nb. 4-5, Legalis [dostęp: 18.05.2018]. 
czenia jego interesów ${ }^{28}$. Wskazać należy, że informacje udzielone konsumentowi przed zawarciem umowy, dotyczące postanowień umownych wpływających na kształt jego praw i obowiązków, oraz informacje odnoszące się do skutków zawarcia kontraktu mają dla niego fundamentalne znaczenie, gdyż właśnie na podstawie tych danych konsument decyduje się zawrzeć umowę zawierająca klauzule sformułowane wcześniej przez przedsiębiorcę ${ }^{29}$.

Nadmienić należy, że zgodnie z art. 15 ust. 5 u.dz.u.r. w przypadku niejednoznacznego sformułowania przez ubezpieczyciela postanowienia zawartego we wzorcu, będzie ono interpretowane na korzyść ubezpieczającego, ubezpieczonego lub uprawnionego z umowy ubezpieczenia, tj. zgodnie z wykładnią in dubio contra proferentem..$^{30}$ Innymi słowy: wykładnia niejednoznacznego postanowienia uniemożliwi uznanie danej klauzuli za nieuczciwą. Jak już zostało wskazane, główne świadczenia stron zaliczają się do elementów przedmiotowo istotnych umowy, a tym samym stanowia jej minimalną treść, bez której dalsze obowiązywanie kontraktu jest niemożliwe. ${ }^{31}$ W związku z powyższym zastosowanie wykładni postanowienia niejednoznacznego dotyczącego głównych świadczeń stron na korzyść konsumenta daje możliwość uzupełnienia w tym zakresie umowy, a tym samym utrzymania jej w mocy. Rozwiązanie to stanowi przejaw poszanowania zasady trwałości umowy i ochrony interesów konsumenta.

\section{Sprzeczność z ustawą a niedozwolony charakter postanowień umownych - natura prawna wzorców umownych a dyspozycja z art. 58 k.c.}

Zagadnienie, czy postanowienie umowne sprzeczne z ustawą może być badane również pod kątem jego abuzywności w rozumieniu art. $385^{1}$ k.c., budzi liczne wątpliwości doktryny. Zgodnie z art. 807 par. 1 k.c. postanowienia ogólnych warunków ubezpieczenia lub postanowienia umowy ubezpieczenia, które są sprzeczne z przepisami k.c. regulującymi umowę ubezpieczenia, są nieważne, chyba że dalsze przepisy przewidują wyjątki. Wskazany przepis stanowi wyłom od ogólnej zasady swobody umów, przewidzianej w art. $353^{1}$ k.c. ${ }^{32}$ Zgodnie z tą zasadą strony moga kształtować wiążący je stosunek prawny według swojego uznania, byleby jego treść i cel nie stał w sprzeczności z naturą tego stosunku, przepisami ustawy oraz zasadami współżycia społecznego. Oznacza to, że w przypadku umowy ubezpieczenia lub ogólnych warunków ubezpieczenia strony mogą modyfikować postanowienia ustawy tylko tam, gdzie z treści przepisu wynika, że ma on charakter dyspozytywny. ${ }^{33}$ Wskazać należy, że na gruncie k.c. ustawodawca ukształtował większość prze-

28. Wyrok SN z dnia 20 czerwca 2006 r., III SK 7/06, Legalis nr 84146 [dostęp: 18.05.2018].

29. Wyrok TSUE z dnia 21 grudnia 2016 r., C-154/15, C-307/15 i C-308/15, EUR-Lex nr 62015CJ0154 [dostęp: 18.05.2018].

30. M. Lemkowski, Materialna ochrona konsumenta, „Ruch Prawniczy, Ekonomiczny i Socjologiczny” 2002, z. 3, s. 69.

31. J. Pisuliński, Sankcja zamieszczenia w umowie niedozwolonego postanowienia w świetle dyrektywy 93/13/ EWG i orzecznictwa TSUE, [w:] Życie umowy konsumenckiej po uznaniu jej postanowienia za nieuczciwe na tle orzecznictwa TSUE, [red] M. Romanowski, CH Beck, Warszawa 2017, s. 9 ?.

32. M. Kondek, Art. 807 k.c., [w:] Kodeks cywilny. Komentarz. Tom III b. Zobowiqzania - część szczegółowa. Ustawa o terminach zapłaty, [red.] K. Osajda, CH Beck, Warszawa 2018, Legalis [dostęp: 18.05.2018].

33. Ibidem. 
pisów regulujących umowę ubezpieczenia jako bezwzględnie wiążące. W związku z tym ryzyko wystapienia sprzeczności postanowień umownych lub ogólnych warunków ubezpieczenia z przepisami ius cogens jest zdecydowanie większe niż w przypadku innych kontraktów. Dlatego też to właśnie w sferze ubezpieczeń rozstrzygnięcie tego zagadnienia jest bardzo istotne. ${ }^{34}$

Na gruncie umowy ubezpieczenia stanowisko sądów w odniesieniu do powyższej kwestii nie było jednolite. Według Sądu Okręgowego w Warszawie - Sąd Ochrony Konkurencji i Konsumentów klauzula umowna sprzeczna z bezwzględnie wiążącymi przepisami jest nieważna zgodnie z art. 58 par. 1 k.c., a w związku z tym nieważność takiego postanowienia powoduje niemożność jego oceny w zakresie zgodności z dobrymi obyczajami i rażącym naruszeniem interesu ubezpieczającego. ${ }^{35}$ Ponadto w ocenie sądu ochrona wynikająca z $385^{1}$ k.c. odnosi się wyłącznie do sytuacji, w której postanowienie wzorca umownego jest ważne, to znaczy zgodne z ustawa. W innych orzeczeniach tego samego sąu kształtował się pogląd przeciwny, w którym sprzeczność klauzul ogólnych warunków ubezpieczenia z przepisami bezwzględnie obowiązującymi nie przesądza o braku możliwości badania tych klauzul pod kątem ich abuzywności, wręcz przeciwnie - stanowi dodatkowy czynnik takiej oceny. ${ }^{36}$

Zdawałoby się, że o rozwiązaniu powyższego zagadnienia miało przesądzić stanowisko Sądu Najwyższego, zgodnie z którym postanowienia wzorca umownego sprzeczne z przepisem ustawy o charakterze bezwzględnie wiążącym nie może być jednocześnie uznane za klauzulę abuzywną w rozumieniu art. $385^{1}$ k.c. ${ }^{37}$ Na wstępie należy zauważyć, że w powyższej uchwale Sąd Najwyższy przyjałł, iż postanowienia wzorca umownego podlegają dyspozycji z art. 58 par. 1 k.c. 0 ile w przypadku umowy ubezpieczenia, która w całości stanowiła przedmiot negocjacji między stronami, będącej bez wạtpienia czynnościa prawną, kwestia objęcia jej dyspozycja powyższego przepisu nie nastarcza większych kontrowersji, o tyle w przypadku wzorca umownego tego typu konkluzja wymaga bliższej analizy. Wskazać należy, że w doktrynie występowały różne teorie dotyczące charakteru prawnego wzorca umownego. Początkowo funkcjonowały dwie przeciwstawne teorie: tzw. teoria normatywistyczna ${ }^{38}$ oraz teoria konsensualistyczna ${ }^{39}$, jednakże z uwagi na zawarte w nich nieprawidłowości zostały one zastapione pogladami pośrednimi. Jedną z takich teorii pośrednich jest koncepcja Ewy Łętowskiej. Zgodnie z tạ teorią wzorce umowne, a tym samym ogólne warunki ubezpieczenia, stanowią kwalifikowane oświadczenie woli przedsiębiorcy, dla których ustawodawca

34. M. Krajewski, Umowa ..., s. 31.

35. Wyrok Sądu Okręgowego w Warszawie - Sąd Ochrony Konkurencji i Konsumentów z dnia 10 października 2005 r., XVII AmC 56/04. Orzeczenie zaczerpnięte z Raportu Rzecznika Ubezpieczonego Klauzule abuzywne w działalności ubezpieczeniowej, luty 2012, s. 13.

36. Wyrok Sądu Okręgowego w Warszawie - Sąd Ochrony Konkurencji i Konsumentów z dnia 11 października 2007 r., XVII AmC 68/06 oraz z dnia 30 października 2007 r., XVII Amc 86/06. Orzeczenia zaczerpnięte z Raportu Rzecznika Ubezpieczeniowego Klauzule abuzywne w działalności ubezpieczeniowej, luty 2012, s. 31-33 oraz 55-56.

37. Uchwała SN z dnia 13 stycznia 2011 r., III CZP 119/10, Legalis nr 284858 [dostęp: 18.05.2018].

38. Por. M. Bednarek, op. cit., s. 609-610 oraz P. Gorzko, Glosa do uchwały SN z dnia 13 stycznia 2011 r., III CZP 119/10, LEX/el. 2012: Wzorzec stanowi oddzielny byt od umowy. Podstawa prawna posługiwania się wzorcem umownym wynikała z zasady autonomii woli stron. W odniesieniu do tej teorii została zakwestionowana możliwość przekazania kompetencji ustawodawcy do tworzenia przepisów prawnych w ramach wzorców innym podmiotom.

39. Por. P. Gorzko, op. cit. Zgodnie z tạ teorią z chwilą zawarcia umowy wzorzec staje się jego częścią i zostaje objęty konsensem stron. Teorii tej zarzucono przyjęcie fikcji konsensu, w przypadkach gdy konsument nie ma wiedzy dotyczącej treści wzorca odgórnie ustalonych przez proponenta. 
przewidział szczególny reżim prawny. ${ }^{40}$ Wskazać należy, że wzorzec umowny przy spełnieniu przewidzianych ustawą przesłanek formalnych (doręczenie wzorca kontrahentowi, umożliwienie kontrahentowi zapoznania się z jego treścią), z mocy samego prawa kształtuje stosunek prawny, który powstał na podstawie umowy zawartej przy pomocy wzorca. ${ }^{41} \mathrm{~W}$ omawianej teorii autorka wskazuje, że wzorzec wpływa na kształt treści stosunku prawnego, tak samo jak to czynia przepisy ustawy, zasady współżycia społecznego i ustalone zwyczaje (art. 56 k.c.). ${ }^{42}$ Oznacza to, że wzorce umowne - a tym samym ogólne warunki ubezpieczenia - są dokumentami, które z uwagi na zawarte w swej treści abstrakcyjne normy mogạ istnieć poza konkretnym stosunkiem ubezpieczeniowym, są zatem elementem zewnętrznym wobec kontraktu i stanowią względem niego niezależny byt. ${ }^{43}$ Podobne stanowisko wyraził Zbigniew Radwański, uznajacc, że wzorzec umowny, który istnieje w oderwaniu od konkretnej umowy, może być traktowany jako specyficzny typ oświadczenia woli lub jako szczególna czynność konwencjonalna. ${ }^{44}$ Inaczej mówiąc, ogólne warunki ubezpieczenia oraz umowa ubezpieczenia stanowią względem siebie samodzielnie „dokumenty”, które wspólnie wyznaczają treść stosunku łączącego ubezpieczyciela z ubezpieczającym. ${ }^{45}$ Kolejną koncepcja pośredniąjest teoria reprezentowana przez Fryderyka Zolla, zgodnie z którą stosowanie wzorca wynika nie z konsensu stron, a wyłącznie z aktu woli proponenta, w związku z czym ustawodawca od drugiej strony kontraktu wymaga tylko zgody na samo zastosowanie wzorca (tzw. zgoda blankietowa). ${ }^{46}$

Należy zaznaczyć, że oba przytoczone poglądy wskazują wprost, że wzorce umowne nie należą do czynności prawnej, a stanowią pewnego rodzaju oświadczenie woli. Ponadto pojęcia „oświadczenie woli” oraz „czynność prawna” nie są synonimami. Zgodnie z poglądem Macieja Gutowskiego między tymi pojęciami nie należy stawiać znaku równości, gdyż oświadczenie woli stanowi jedynie część składową czynności prawnej. ${ }^{47}$ Reasumując - zgodnie z dominującym poglądem należy uznać, że wzorce umowne niebędące czynnością prawną nie podlegają dyspozycji z art. 58 k.c., a tym samym nie powinny być one badane w świetle tej regulacji. Ustawodawca wprowadził dla wzorców umownych szczególny reżim prawny przewidujący badanie ich jedynie pod względem abuzywności. Ponadto w orzecznictwie wskazuje się, że sąd powinien z urzędu uwzględniać niedozwolony charakter postanowienia umownego, nawet w przypadku gdy zarzut ten nie zostanie podniesiony przez konsumenta. ${ }^{48}$

Mimo takiego ukształtowania przez doktrynę koncepcji natury prawnej wzorców umownych w praktyce sądów w dalszym ciagu dostrzec można orzekanie o sprzeczności postanowień wzorca z ustawą w oparciu o art. 58 k.c., mimo iż przepis ten wprost stanowi, że znajduje zastosowanie jedynie do czynności prawnych. Praktykę tę zdaje się tłumaczyć stanowisko, zgodnie z którym zakres przedmiotowy nieważności wskazanego przepisu obejmuje również oświadczenia woli składane

40. M. Bednarek, op. cit., s. 67?.

41. Ibidem.

42. M. Krajewski, Umowa ..., s. 201-202.

43. A. Mlostoń-Olszewska, Możliwość orzekania o uznaniu za niedozwolone postanowień wzorca umowy sprzecznych z bezwzględnie obowiqzujacymi przepisami prawa - argumenty za i przeciw, [w:] Prawo konsumenckie w praktyce, [red.] M. Czarnecka, T. Skoczny, CH Beck, Warszawa 2016, Legalis [dostęp: 18.05.2018].

44. Radwański Z., Olejniczak A., Zobowiqzania - część ogólna, CH Beck, Warszawa 2006, s. 153.

45. M. Wałachowska, Wzorce umowne po wejściu w życie nowej ustawy o działalności ubezpieczeniowej i reasekuracyjnej (zagadnienia wybrane), „Wiadomości Ubezpieczeniowe” 2016, nr 3, s. 4-5.

46. M. Bednarek, op. cit., s. 676 .

47. M. Gutowski, Nieważność czynności prawnej, CH Beck, Warszawa 2017, Legalis [dostęp: 18.05.2018].

48. Wyrok TSUE z dnia z dnia 30 maja 2013 r., C-397/11, LEX [dostęp: 18.05.2018]. 
w trybie ofertowym, przetargu czy też aukcji. ${ }^{49}$ Sąd Najwyższy uznając, że wzorzec umowny (a więc także ogólne warunki ubezpieczenia] stanowi integralną część umowy, przyjałł nieco szerszy zakres pojęcia czynności prawnej, rozszerzając te ostatnie na jej części składowe w postaci oświadczeń woli. Jednakże takie założenie należałoby uznać za błędne, gdyż wadliwość oświadczenia woli może jedynie wpłynać na ważność czynności prawnej. ${ }^{50}$ Innymi słowy, konsekwencja wadliwego oświadczenia woli jest możliwość uznania czynności prawnej, w ramach której oświadczenie zostało złożone, za nieważną w świetle art. 58 k.c. Ustawodawca wprowadził bowiem w k.c. odrębne od przewidzianych w art. 58 k.c. podstawy umożliwiające stwierdzenie wadliwości oświadczeń woli, w związku z czym podlegają one badaniu w oparciu o rodzaje wadliwości przewidziane w art. 82-88 k.c., do których zalicza się stan wyłączający świadome albo swobodne powzięcie decyzji i wyrażenia woli, pozorność, błą, zniekształcenie przez posłańca, podstęp lub groźbę.

\section{Sankcja niezwiązania niedozwolonym postanowieniem umownym a sankcja nieważności}

\subsection{Uwagi ogólne}

Co do zasady podstawowy skutek stwierdzenia abuzywności danego postanowienia jest podobny do tego, który wynika z art. 58 k.c., tj. nieważności bezwzględnej. W obu bowiem przypadkach celem sankcji jest uniemożliwienie danej klauzuli umownej wywołania określonego skutku prawnego. ${ }^{51}$ Ponadto wskazać należy, że obie sankcje mają zastosowanie ex lege, to znaczy z mocy samego prawa oraz wywierają skutki ex tunc, czyli od chwili zawarcia umowy. ${ }^{52}$ Jednakże mimo wskazanych podobieństw sankcje te istotnie się różnią. W orzecznictwie podjęto próbę wskazania zasadniczej różnicy pomiędzy bezskutecznością a nieważnością. Sạd przyjął, że w przeciwieństwie do sankcji nieważności bezskuteczność odnosi się do nieprawidłowości, które wynikają z zamiaru stron wykonujących daną czynność prawną, a nie do wadliwości tkwiącej w samej czynności prawnej ${ }^{53}$.

\subsection{Zakres zachowania mocy wiążącej umowy po eliminacji niedozwolonego postanowienia umownego.}

W przypadku wystapienia niedozwolonych postanowień w umowie (wzorcu umownym) zawartej pomiędzy profesjonalistą a konsumentem ustawodawca wprowadził sankcję w postaci bezskuteczności klauzul abuzywnych. Wprowadzenie tego rodzaju sankcji w odniesieniu do niedozwolonych klauzul stanowi przejaw wdrożenia do polskiego systemu prawnego dyrektywy 93/13, jednakże wskazać należy, że w toku prac legislacyjnych rozważano również wprowadzenie w art. $385^{1}$ k.c.

49. P. Machnikowski, Art. 58 k.c. Kodeks cywilny. Komentarz, Gniewek E., [red.] P. Machnikowski, CH Beck, Warszawa 2017, nb. 7, Legalis [dostęp: 18.05.2018].

50. P. Sobolewski, Art. 58 k.c., [w:] Kodeks cywilny. Komentarz. Tom I. Część ogólna, [red.] K. Osajda, CH Beck, Warszawa 2018, Legalis [dostęp: 18.05.2018].

51. P. Gorzko, op. cit.

52. Por. Wyrok SN z dnia 13 stycznia 2011 r., III CZP 119/10, Legalis nr 284858 [dostęp: 18.05.2018] oraz Wyrok SN z dnia 7 kwietnia 2010 r., II UK 357/09, Legalis nr 316875 [dostęp: 18.05.2018].

53. Wyrok SA w Krakowie z dnia 16 stycznia 2015 r., I ACa 1493/14, LEX nr 1659076 [dostęp: 18.05.2018]. 
sankcji nieważności. ${ }^{54}$ Sankcja bezskuteczności oznacza, że postanowienie umowne, które spełnia kumulatywnie wszystkie przesłanki abuzywności, nie wiąże konsumenta, natomiast jak słusznie zauważył Jerzy Pisuliński, przedsiębiorca jest nim dalej związany, jeżeli konsument wywodzi dla siebie określone prawo z takiej klauzuli. ${ }^{55}$ Przepis ten ma bezwzględnie wiążący charakter, czego celem jest przywrócenie równej pozycji stron umowy poprzez zastapienie ustanowionej w umowie dysproporcji uprawnień i obowiązków stron w równowagę rzeczywistą ${ }^{56}$ poprzez wyeliminowanie z treści umowy nieuczciwego postanowienia.

Ponadto należy zaznaczyć, że zastosowanie sankcji bezskuteczności nie powoduje bezskuteczności treści całej umowy, gdyż wyłączenie klauzuli abuzywnej nie wpływa na pozostałe postanowienia umowne, które w dalszym ciaggu wiążą strony. Jednakże w takiej sytuacji mamy do czynienia z pewnego rodzaju luką, która powstała w umowie lub wzorcu poprzez wyłączenie stosowania niedozwolonego postanowienia. W związku z tym należy zastanowić się, czy na gruncie obowiązujących regulacji prawnych istnieje możliwość uzupełnienia takiego postanowienia. W jednym z orzeczeń Trybunał Sprawiedliwości uznał, że sądy krajowe są obowiązane do zaniechania stosowania niedozwolonego postanowienia umownego, aby nie mogło ono wywrzeć żadnych skutków wobec konsumenta. Jednocześnie orzekł, że nie posiadaja one uprawnienia do zmiany treści takiej klauzuli5? Innymi słowy, umowa obowiąuje strony, bez jakiejkolwiek ingerencji sądu w jej dotychczasową treść poza eliminacją nieuczciwej klauzuli. Trybunał bowiem wskazał, że przyznanie sądom uprawnienia do modyfikacji treści nieuczciwego postanowienia mogłoby się przyczynić do dalszego stosowania przez przedsiębiorców niedozwolonych klauzul, ze świadomością, że wprawdzie są one abuzywne, ale sąd ma możliwość zmiany ich treści, w ten sposób, aby zagwarantować interes przedsiębiorcy ${ }^{58}$. Innymi słowy, dalsze obowiązywanie umowy z wyłączeniem nieuczciwego postanowienia ma stanowić dla przedsiębiorcy dodatkowy czynnik zniechęcający go do stosowania niedozwolonych klauzul.

W następnej kolejności należy odnieść się do jednej z zasadniczych różnić pomiędzy omawianymi sankcjami. Mianowicie art. 58 par. 1 k.c. przewiduje, że w przypadku sprzeczności czynności prawnej z ustawą przepis szczególny może przewidywać inny skutek, w szczególności że w miejsce nieważnego postanowienia moga mieć zastosowanie przepisy o charakterze dyspozytywnym. Ponadto, zgodnie z orzeczeniem Trybunału Sprawiedliwości, w przypadku gdy umowa z udziałem konsumenta nie może obowiązywać po wyeliminowaniu z jej treści niedozwolonego postanowienia, sąd krajowy - aby zaradzić skutkom nieważności tej klauzuli - może zastapić ją przepisami o charakterze dyspozytywnym. ${ }^{59}$ Zastapienie niedozwolonego postanowienia umownego przepisem prawa, który umożliwia dalsze obowiązywanie umowy, znajduje całkowite poparcie w świetle dyrektywy 93/13. ${ }^{60}$ W polskim systemie prawnym nie został wprowadzony przepis szczególny, który mimo aprobaty na szczeblu unijnym, umożliwiałby uzupełnienie umowy takimi przepisami. Oznacza to,

54. A. Kołodziej, Charakterystyka cywilnoprawnej sankcji niedozwolonych postanowień w umowach z konsumentami, „Rejent” 2008, nr 12, s. 599.

55. J. Pisuliński, op. cit., s. 9 ?

56. Wyrok TSUE z dnia 21 grudnia 2016, C-119/15, Legalis nr 1564656 [dostęp: 18.05.2018].

57. Wyrok TSUE z dnia 14 czerwca 2012, C-618/10, Legalis nr 483548 [dostęp: 18.05.2018].

58. Ibidem.

59. Wyrok TSUE z dnia 30 kwietnia 2014 r., C-26/13, LEX [dostęp: 18.05.2018],

60. Ibidem. 
że nieuczciwe postanowienie nie powoduje, że na jego miejsce wchodzi dyspozycja normy prawnej o charakterze dyspozytywnym. ${ }^{61}$ W związku z tym należałoby się odnieść do kwestii, które z powyższych rozwiązań w większym stopniu zabezpiecza interesy konsumenta. Wskazać należy, że przepisy o charakterze względnie wiążącym kształtuja modelowe rozłożenie tych uprawnień i obowiązków stron umowy, które mogą być przez nie modyfikowane w granicach poszanowania wzajemnych interesów. ${ }^{62}$ Oznacza to w praktyce, że strony moga podjąć decyzję, czy zamierzają uregulować wiążący je stosunek prawny w sposób odmienny od modelowego przewidzianego w przepisach dyspozytywnych, czy też chcą pozostawić tę kwestię nieuregulowaną i w związku z tym w miejsce tej luki zastosowanie znajda przepisy dyspozytywne. Tego typu rozwiązanie, polegające na uzupełnieniu umowy przepisem dyspozytywnym, w przypadku wystapienia luki wywołanej wyłączeniem z jej treści nieuczciwej klauzuli odnoszącej się do głównych świadczeń stron wydaje się lepiej zabezpieczać interesy konsumenta. Wskazać należy, że usunięcie z umowy postanowienia, które dotyczy elementów przedmiotowo istotnych, powoduje, że traci ona wymaganą prawem minimalną treść potrzebną dla istnienia danego stosunku. ${ }^{63}$ Ponadto w sytuacji, w której w wyniku wyłączenia klauzuli abuzywnej dotyczącej głównego świadczenia i niemożności ustalenia jego treści przy pomocy art. 56 k.c., przy jednoczesnym uniemożliwieniu uzupełnienia powstałej luki przepisami dyspozytywnymi, sytuacja ta doprowadzi do upadku całej umowy ${ }^{64}$, co w odniesieniu do osoby konsumenta, a na gruncie umowy ubezpieczenia także w odniesieniu do drobnych przedsiębiorców w większości przypadków nie będzie stanowiło pożądanego skutku.

W następnej kolejności należy odnotować, że w art. $385^{1}$ par. 1 i 2 k.c. została zdefiniowana bezskuteczność częściowa umowy, przy czym treść dyspozycji tych ustępów nie jest tożsama z regulacją z art. 58 par. 3 k.c., tj. częściową nieważnością. Oznacza to, że nieskuteczna klauzula abuzywna nie ma wpływu na skuteczność pozostałych postanowień umowy lub wzorca, gdyż przepis ten nie przewiduje możliwości oceny, czy bez takich postanowień kontrahenci zawarliby umowę. ${ }^{65}$ W praktyce oznacza to, że ubezpieczyciel nie może uchylać się od realizacji umowy, w przypadku gdy z jej treści zostanie wyeliminowana nieuczciwa klauzula. Powyższe znajduje swoje odzwierciedlenie w orzeczeniu Sadu Najwyższego, zgodnie z którym eliminacja z umowy klauzuli abuzywnej nie powoduje nieważności całej umowy nawet wtedy, gdy bez takiego postanowienia umowa nie zostałaby zawarta. ${ }^{66}$ Wskazać należy, że rozwiązanie przyjęte przez polskiego ustawodawcę odbiega od regulacji zawartej w dyrektywie 93/13. Zgodnie z jej art. 6 niedozwolone postanowienia umowne nie wiążą konsumenta, a umowa w pozostałej części jest nadal skuteczna, chyba że jest to niemożliwe z uwagi na wyłączenie z jej treści nieuczciwej klauzuli. Jednakże z uwagi na fakt, że dyrektywa 93/13 określa jedynie minimalne wymogi ochrony konsumenta przed nieuczciwymi klauzulami, to przyjęte w polskim porządku prawnym rozwiązanie w żaden sposób

61. Por. C. Żuławska, Art. 58 k.c., [w:] Komentarz do Kodeksu cywilnego. Księga trzecia. Zobowiqzania. Tom I, [red.] J. Gudowski, CH Beck, Warszawa 2001, s. 131.

62. M. Bednarek, op. cit., s. 766-767.

63. J. Pisuliński, op. cit., s. 93-94.

64. M. Lemkowski, op. cit., s. 88.

65. A. Olejniczak, Art. 3851, [w:] Kodeks cywilny. Komentarz. Tom III. Zobowiqzania-część ogólna, [red.] A. Kidyba, Wolters Kluwer, Warszawa 2014, Legalis [dostęp: 18.05.2018].

66. Wyrok SN z dnia 21 lutego 2013 r., I CSK 408/12, Legalis nr 719201 [dostęp: 18.05.2018]. 
nie narusza postanowień unijnej dyrektywy. ${ }^{67}$ Przyjęte rozwiązanie uznać należy za korzystne dla ubezpieczającego w umowie ubezpieczenia, gdyż respektuje ono zasadę trwałości umowy. Ubezpieczający, zawierając z ubezpieczycielem umowę ubezpieczenia, ma na celu zapewnienie sobie lub innemu podmiotowi ochrony ubezpieczeniowej i - w razie ziszczenia się wypadku określonego w umowie - uzyskanie od ubezpieczyciela odpowiedniego świadczenia. Warto zauważyć, że ubezpieczyciele, z uwagi na masowy charakter umów ubezpieczenia, posługuja się zazwyczaj ogólnymi warunkami ubezpieczenia których treść zawiera postanowienia standardowe dla danego rodzaju ubezpieczenia. ${ }^{68} \mathrm{Z}$ uwagi na standaryzację postanowień ogólnych warunków ubezpieczenia nie są one przedmiotem indywidualnych negocjacji z potencjalnym ubezpieczającym, a zawarte w nich postanowienia dość często są wygodne z punktu widzenia interesu ubezpieczyciela, a niekorzystne dla ubezpieczającego. ${ }^{69}$ Dlatego też dalsze obowiązywanie umowy, z wyłączeniem nieuczciwego postanowienia, zmusza przedsiębiorcę do realizacji kontraktu, pomimo tego, że z jego treści została wyeliminowana klauzula, która miała mu przysporzyć dodatkowe korzyści. ${ }^{\text {0 }}$

\subsection{Zakres zastosowania sprzeczności z dobrymi obyczajami jako przesłanka stwierdzenia nieważności czynności prawnej a inne jej podstawy w postaci sprzeczności z ustawą albo zasadami współżycia społecznego}

W odniesieniu do nieważności bezwzględnej z art. 58 k.c. przepis ten wskazuje trzy podstawy uznania danej czynności prawnej za nieważną. Są to: sprzeczność z ustawą, dokonanie czynności w celu obejścia ustawy oraz sprzeczność z zasadami współżycia społecznymi. Analizie zostaną poddane tylko dwie z wymienionych podstaw tj. sprzeczność z ustawą oraz sprzeczność z zasadami współżycia społecznego, albowiem w odniesieniu do przesłanki sprzeczności z dobrymi obyczajami obje te podstawy wykazuja pewne podobieństwo.

Odnośnie do pierwszej z wymienionych podstaw, wskazać należy, że stan „sprzeczności” danej czynności prawnej z ustawą występuje w sytuacji, gdy treść lub sposób dokonania tejże czynności jest sprzeczny z przepisami prawa. ${ }^{71} \mathrm{~W}$ literaturze i orzecznictwie funkcjonuje jednolity pogląd, wskazujący, że sankcja nieważności ma zastosowanie w przypadku dokonania czynności prawnej sprzecznej z przepisami bezwzględnie wiążącymi (ius cogens). ${ }^{72}$ W odniesieniu do przepisów dyspozytywnych znaczna część doktryny staje na stanowisku, że sprzeczność czynności prawnej z przepisami o charakterze względnie wiążącym objęta jest również dyspozycją z art. 58 par. 1 k.c. ${ }^{73}$ W przypadku gdy dana klauzula umowna pozostaje w sprzeczności z ustawą, a jednocześnie może być uznana za niedozwoloną w rozumieniu art. $385^{1}$ k.c., wówczas - zgodnie ze stanowiskiem Sądu Najwyższego - postanowienie takie z powodu niemożności wywarcia

67. A. Mlostoń-Olszewska, op. cit.

68. M. Orlicki, Ubezpieczenia, [w:] Prawo umów handlowych, [red.] M. Stec, CH Beck, Warszawa 2017, nb. 14, Legalis [dostęp: 18.05.2018].

69. S. Wieteska, op. cit., s. 129.

70. A. Mlostoń-Olszewska, op. cit.

71. P. Sobolewski, op. cit.

72. Ibidem.

73. Por. M. Gutowski, Art. 58 k.c., [w:] Kodeks cywilny. Tom I. Komentarz. Art. 1-44911, Gutowski M. [red.], CH Beck, Warszawa 2016, nb. 22; M. Safjan, Art. 58 k.c., [w:] Kodeks cywilny. Tom I. Komentarz od art. 1-44910, Pietrzykowski K. [red.], CH Beck, Warszawa 2018, nb. 6, Legalis [dostęp: 18.05.2018]. 
skutku prawnego nie może wpłynąć na kształt uprawnień i zobowiązań konsumenta, a z tego też powodu nie może rażąco naruszyć jego interesów. Zdaniem Sądu w takiej sytuacji dana klauzula, nie może podlegać ocenie pod względem przesłanek z art. $385^{1}$ k.c., w szczególności z punktu widzenia zgodności z dobrymi obyczajami. ${ }^{24}$ Mając powyższe na uwadze, należy zastanowić się nad zakresem zastosowania tej przesłanki w odniesieniu do wskazanych podstaw nieważności $\mathrm{z}$ art. $58 \mathrm{k} . \mathrm{c}$.

W pierwszej kolejności przyjęty przez sąd pogląd, że postanowienie sprzeczne z przepisami ius cogens nie może kształtować uprawnień i obowiązków konsumenta, a tym samym naruszyć jego interesów, budzi kontrowersje, albowiem celem sankcji bezskuteczności tak samo jak sankcji nieważności jest uniemożliwienie wywołania przez dane postanowienie określonego skutku prawnego. Ponadto, jak zostało wskazane, bezskuteczność ma zastosowanie ze skutkiem ex tunc, co oznacza, że postanowienie takie nie będzie wiązało konsumenta już od samego początku zawarcia umowy, w związku z tym nie dojdzie do rzeczywistego ukształtowania jego pozycji z pokrzywdzeniem jego interesów. Przyjąć należy, że przepis art. $385^{1}$ k.c. dotyczy samej próby kształtowania praw i obowiązków konsumenta z pokrzywdzeniem jego interesów, a zatem hipotetycznego naruszenia pozycji kontraktowej konsumenta. ${ }^{25}$

Ponadto ustawodawca, definiując niedozwolone postanowienia umowne, nie przewidział wprost w art. $385^{1}$ k.c., że klauzule te muszą być zgodne z ustawa. Jak zostało wskazane w części dotyczącej niedozwolonych postanowień umownych, za sprzeczne z dobrymi obyczajami należy uznać takie ukształtowanie praw i obowiązków stron przez przedsiębiorcę, które narusza ich równowagę kontraktowa, prowadząc do dysproporcji praw i obowiązków stron. Odnotować należy, że przepisy o charakterze względnie wiążącym kształtują modelowe rozłożenie uprawnień i obowiązków stron umowy, które mogą być przez nie modyfikowane. Zgodnie z koncepcją Przemysława Gorzki w sytuacji, gdy dane postanowienie umowne rażąco narusza równowagę pozycji prawnej stron poprzez ukształtowanie ich praw i obowiązków w sposób istotnie odbiegający od sposobu określonego w przepisach dyspozytywnych, tego typu działanie należy uznać za spełniające przesłankę sprzeczności z dobrymi obyczajami, naruszające interesy konsumenta, chronione przepisami dyspozytywnymi przy jednoczesnym naruszeniu tych przepisów. ${ }^{? 6}$ Według autora skoro sprzeczność z przepisami dyspozytywnymi mieści się w zakresie sprzeczności z dobrymi obyczajami, to tym bardziej postanowienia sprzeczne z przepisami o charakterze bezwzględnie wiążącym naruszają zaufanie stron umowy, a tym samym wypełniają treść przesłanki sprzeczności z dobrymi obyczajami. $7 ?$ Mając to na uwadze, można się przychylić do stwierdzenia, że przesłanka dobrych obyczajów swoim zakresem obejmuje również badanie klauzuli pod kątem jej sprzeczności z ustawą. ${ }^{78}$

W związku z powyższym można przychylić się do poglądu części doktryny, zgodnie z którym - w myśl reguły lex specialis derogat legi generali - w przypadku kolizji nieważności z art. 58 k.c. z bezskutecznością z art. $358^{1}$ par. 1 k.c. należy stosować wyłącznie sankcję przewidziana

74. Uchwała SN z dnia 13 stycznia 2011 r., III CZP 119/10, Legalis nr 284858 [dostęp: 18.05.2018].

75. M. Krajewski, Umowa ..., s. 33.

76. P. Gorzko, op. cit.

77. Ibidem.

78. Ibidem. 


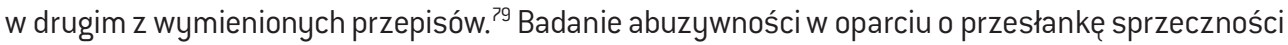
z dobrymi obyczajami obejmuje swoim zakresem również badanie klauzuli pod kątem sprzeczności z ustawa, a tym samym w razie stwierdzenia nieuczciwego charakteru klauzuli sprzecznej z przepisami ustawy zastosowanie ma sankcja bezskuteczności jako skutek przewidziany przepisem szczególnym. Taka konkluzja zdaje się znajdować poparcie w przepisach prawa, albowiem zgodnie z art. 58 par. 1 k.c. nie zawsze czynność sprzeczna z ustawą pociąga za sobą sankcję bezwzględnej nieważności. W analizowanym przepisie ustawodawca wprost przewidział, że sankcja nieważności nie ma zastosowania, jeżeli przepis szczególny przewiduje inny skutek.

Ponadto wskazać należy, że klauzulę generalną odwołującą się do zasad współżycia społecznego, stanowiącą kolejną z podstaw nieważności czynności prawnej, w doktrynie utożsamia się z pojęciem dobrych obyczajów. W literaturze wskazuje się, że poprzez wprowadzenie do polskiego systemu prawnego klauzuli dobrych obyczajów ustawodawca stopniowo dąży do eliminacji klauzuli generalnej dotyczącej zasad współżycia społecznego. ${ }^{80}$ Innymi słowy: klauzula dobrych obyczajów stosowana jest niekiedy zamiennie z klauzulą zasad współżycia społecznego. Stwierdzenie, że obie klauzule można stosować zamiennie, należałoby uznać za zbyt duże uproszczenie, albowiem zdefiniowanie obu klauzul generalnych jest bardzo problematyczne, gdyż określenie wzajemnej relacji pomiędzy nimi wymaga odniesienia się do kryteriów oraz wartości, do których odwołują się te klauzule. Wskazać należy, że zarówno klauzula zasad współżycia społecznego, jak i klauzula dobrych obyczajów zostały wprowadzone do polskiego systemu w celu uelastycznienia prawa. W odniesieniu do wartości, do których odsyła klauzula generalna zasad współżycia społecznego, w literaturze wskazuje się na moralność, obyczajowość, wartości wyrażone w prawie pozytywnym czy reguły postępowania w życiu społecznym. ${ }^{81}$ Natomiast do kryteriów dobrych obyczajów zalicza się m.in. moralność, uczciwość, obyczajowość, przyzwoitość oraz poczucie prawnej sprawiedliwości. ${ }^{82}$ Ponadto, jak wynika z literatury, wartości, do których nawiązywały zasady współżycia społecznego, od samego początku obowiązywania klauzuli odnoszono do moralności, podobnie pojęcie dobrych obyczajów" kojarzone jest z normami moralnymi. ${ }^{83}$ Przyjmując jako kryterium pojęcie moralności, można by przychylić się do stwierdzenia, że zakres tych klauzul jest tożsamy. Jednakże wskazać należy, że kryterium moralności jest jednym z wielu, do których powyższe klauzule odsyłają, a ponadto samo pojęcie moralności może być interpretowane w różnoraki sposób. ${ }^{84} \mathrm{~W}$ związku z tym właściwszym rozwiązaniem jest przyjęcie, że pomiędzy obiema klauzulami generalnymi zachodzi stosunek krzyżowania. Reasumując: postanowienie umowne będące w sprzeczności z zasadami współżycia społecznego pozostaje w stosunku krzyżowania z naruszeniem przesłanki sprzeczności z dobrymi obyczajami z art. $385^{1}$ k.c.

79. Por. P. Sobolewski, op. cit.; M. Safjan, op. cit., s. 335 i 341; W. Popiołek, op. cit., s. 140 i 182; M. Lemkowski, op. cit., s. 89; M. Bednarek, op. cit., s. ?73-774.

80. M. Bednarek, op. cit., s. 76 ?

81. K. Kopaczyńska-Pieczniak, Dobre obyczaje i zasady współżycia społecznego w prawie spółek handlowych, „Annales Universitatis Mariae Curie-Skłodowska” 2016, vol. 63, nr 2, s. 96.

82. Ibidem, s. 9 ?.

83. A. Żurawik, Dobre obyczaje a zwyczaje, zasady współżycia społecznego i dobra wiara: ujęcie teoretyczne, „Kwartalnik Prawa Publicznego” 2007, nr 7/4, s. 206.

84. Ibidem, s. 20? 


\section{Podsumowanie}

Mając na uwadze adhezyjny charakter umowy ubezpieczenia i posługiwanie się w większości przypadków przez ubezpieczycieli wzorcami umownymi, wskazać należy, że natura prawna wzorca jako kwalifikowanego oświadczenia woli nie należy do kategorii czynności prawnych, dlatego też nie powinna podlegać badaniu w świetle art. 58 k.c. Ustawodawca wprowadził do polskiego systemu specyficzny reżim prawny, w którym przewidział jedynie sankcję bezskuteczności w przypadku niedozwolonego charakteru postanowień umownych. Wskazać należy, że w przypadku pozostawania w sprzeczności z ustawą klauzuli nieuczciwej, poprzez wprowadzenie jako jednej z przesłanek abuzywności zasady dobrych obyczajów (dobrej wiary), która swoim zakresem obejmuje badanie danej klauzuli również pod kątem zgodności z przepisami prawa oraz zasadami współżycia społecznego, uznać należy, że sankcja bezskuteczności powinna mieć wyłączne zastosowanie.

Ponadto, mając na względzie dominujący pogląd doktryny dotyczący uznania art. $385^{1}$ k.c. za lex specialis względem przepisu 58 k.c., należy przychylić się do stwierdzenia, że na gruncie umowy ubezpieczenia sankcja bezskuteczności z art. $385^{1}$ k.c. lepiej zabezpiecza interesy ubezpieczajacego. Respektując zasadę trwałości umów, powoduje ona bowiem jedynie eliminację nieuczciwej klauzuli umownej, zachowując w niezmienionym kształcie pozostałą część umowy i pozbawiając sąd uprawnienia do modyfikacji nieuczciwego postanowienia. Jednakże w odniesieniu do możliwości zastapienia wyłączonego postanowienia umownego przepisem o charakterze dyspozytywnym, gdy postanowienie to dotyczy głównych świadczeń stron, przyjąc należy, że tego typu rozwiązanie jest korzystniejsze dla ubezpieczającego, gdyż poprzez zastosowanie dyspozycji przepisu dyspozytywnego dojdzie do uzupełnienia umowy o treści, bez których nie mogłaby ona obowiązywać, a tym samym czyni to zadość zasadzie trwałości umów.

W odróżnieniu od sankcji nieważności sankcja bezskuteczności nie pociaga za sobą konieczności przeprowadzania oceny, czy bez nieuczciwych klauzul strony zawarłyby umowę. W konsekwencji wymusza to na przedsiębiorcy realizację kontraktu pomimo eliminacji z jej treści nieuczciwego warunku, co przekłada się na zapewnienie ubezpieczającemu - jako słabszej stronie w relacjach z ubezpieczycielem - odpowiedniego poziomu ochrony.

\section{Wykaz źródeł}

Bednarek M., Wzorce umów, [w:] System prawa prywatnego. Tom 5. Prawo zobowiqzań - część ogólna, Łętowska E. [red.], CH Beck, Warszawa 2013.

Bukowska E., Art. 15, [w:] Ustawa o działalności ubezpieczeniowej i reasekuracyjnej. Komentarz, Czublun P. [red.], CH Beck, Warszawa 2016.

Gorzko P., Glosa do uchwały SN z dnia 13 stycznia 2011 r., III CZP 119/10.

Gutowski M., Art. 58 k.C., [w:] Kodeks cywilny. Tom I. Komentarz. Art. 1-449 $9^{11}$, Gutowski M. [red.],

CH Beck, Warszawa 2016.

Gutowski M., Bezskuteczność czynności prawnej, CH Beck, Warszawa 2017.

Gutowski M., Nieważność czynności prawnej, CH Beck, Warszawa 2017.

Kołodziej A., Charakterystyka cywilnoprawnej sankcji niedozwolonych postanowień w umowach z konsumentami, „Rejent” 2008, nr 12. 
Kondek M., Art. 807 k.c., [w:] Kodeks cywilny. Komentarz. Tom III b. Zobowiqzania - część szczegółowa. Ustawa o terminach zapłaty, Osajda K. [red.], CH Beck, Warszawa 2018.

Kopaczyńska-Pieczniak K., Dobre obyczaje i zasady współżycia społecznego w prawie spółek handlowych, „Annales Universitatis Mariae Curie-Skłodowska” 2016, vol. 63, nr 2.

Krajewski M., Umowa ubezpieczenia a niedozwolone postanowienia umowne, „Wiadomości Ubezpieczeniowe", 2013, nr 1 (specjalny).

Krajewski M., Umowa ubezpieczenia. Art. 805-834 k.c. Komentarz, CH Beck, Warszawa 2016. Lemkowski M., Materialna ochrona konsumenta, „Ruch Prawniczy, Ekonomiczny i Socjologiczny” 2002, z. 3.

Łętowska E., Ochrona niektórych praw konsumentów. Komentarz, CH Beck, Warszawa 2001.

Machnikowski P., [w:] Kodeks cywilny. Komentarz, Gniewek E., Machnikowski P. [red.], CH Beck, Warszawa 201?.

Machnikowski P., Art. 58 k.c., [w:] Kodeks cywilny. Komentarz, Gniewek E., Machnikowski P. [red.], CH Beck, Warszawa 2017.

Mlostoń-Olszewska A., Możliwość orzekania o uznaniu za niedozwolone postanowień wzorca umowy sprzecznych z bezwzględnie obowiq̨ujacymi przepisami prawa - argumenty za i przeciw, [w: ] Prawo konsumenckie w praktyce, Czarnecka M., Skoczny T. [red.], CH Beck, Warszawa 2016. Olejniczak A., Art. 385¹, [w:] Kodeks cywilny. Komentarz. Tom III. Zobowiqzania - część ogólna, Kidyba A. [red.], Wolters Kluwer, Warszawa 2014.

Orlicki M., Umowa ubezpieczenia, [w:] Prawo umów handlowych, Stec M. [red.], CH Beck, Warszawa 2017.

Pisuliński J., Sankcja zamieszczenia w umowie niedozwolonego postanowienia w świetle dyrektywy 93/13/EWG i orzecznictwa TSUE, [w:] Życie umowy konsumenckiej po uznaniu jej postanowienia za nieuczciwe na tle orzecznictwa TSUE, Romanowski M. [red], CH Beck, Warszawa 2017. Popiołek W., Art.358 ${ }^{1}$, [w:] Kodeks cywilny. Tom I. Komentarz od art. 1-449 ${ }^{10}$, Pietrzykowski K. [red.], CH Beck, Warszawa 2018.

Radwański Z., Olejniczak A., Zobowiqzania - część ogólna, CH Beck, Warszawa 2006.

Raport Rzecznika Ubezpieczeniowego Klauzule abuzywne w działalności ubezpieczeniowej, luty 2012. Rejdak M., Definicja terminu „wzorzec umowy konsumenckiej”, „Ruch Prawniczy, Ekonomiczny i Socjologiczny" 2005, z. 3.

Safjan M., Art. 58 k.C., [w:] Kodeks cywilny. Tom I. Komentarz od art. 1-44910, Pietrzykowski K. [red.], CH Beck, Warszawa 2018.

Sikorski R., Ruchała P., Art. 3851, [w:] Kodeks cywilny. Tom I. Komentarz. Art. 1-44911, Gutowski M. [red.], CH Beck, Warszawa 2016.

Sobolewski P., Art. 58 k.c., [w:] Kodeks cywilny. Komentarz. Tom I. Część ogólna, Osajda K. [red.], CH Beck, Warszawa 2018.

Wałachowska M., Wzorce umowne po wejściu w życie nowej ustawy o działalności ubezpieczeniowej i reasekuracyjnej (zagadnienia wybrane), „Wiadomości Ubezpieczeniowe” 2016, nr 3.

Wieteska S., Nieuczciwe praktyki na rynku ubezpieczeniowym - klauzule abuzywne, „Annales. Etyka w życiu gospodarczym" 2011, nr 2.

Żuławska C., Art. 58 k.c., [w:] Komentarz do Kodeksu cywilnego. Księga trzecia. Zobowiqzania. Tom I, Gudowski J. [red], CH Beck, Warszawa 2001.

Żurawik A., Dobre obyczaje a zwyczaje, zasady współżycia społecznego i dobra wiara: ujęcie teoretyczne, „Kwartalnik Prawa Publicznego” 2007, nr 7/4. 


\section{Ineffectiveness and invalidity of unfair contract terms in insurance contracts}

The purpose of this article is to determine which sanction - ineffectiveness or invalidity - on the basis of an insurance contract concluded using the general terms and conditions of insurance, in the event that unfair contract terms appear in its content that are at the same time contrary to the law or rules of social existence, better secures the interests of the insured. The insurance contract is one of the contracts which are predominantly adhesive. The mass nature of insurance contracts and the need to provide the policyholder with an adequate level of protection, they have contributed to shaping the regulations regarding the insurance contract for the most part in the form of regulations ius cogens. In view of the above, there is a high probability in relation to the insurance contract, that the terms of the standard pattern formulated by the insurer may also satisfy the conditions of art. $385^{1}$ of the Civil Code (c.c.) indicating the unlawful nature of clauses, and at the same time be in contrary to the law or rules of social existence. In such a case, the doubt appears, whether to apply the sanction of invalidity from art. 58 c.c., or ineffectiveness from art. $385^{1}$ c.c.

Key words: unfair contract terms, abusive clauses, contract pattern, general terms and conditions of insurance, ineffectiveness, invalidity, insurance contract.

MGR ALEKSANDRA WOJCIECHOWSKA - absolwentka Wydziału Prawa i Administracji Uniwersytetu Gdańskiego. 